Przegląd Prawa Konstytucyjnego

-----ISSN 2082-1212-----

DOI 10.15804/ppk.2021.05.31

-----Nr $5(63) / 2021-----$

Joanna Karolina Eubina ${ }^{1}$

\title{
Rola regionalnych izb obrachunkowych w zakresie nadzoru i kontroli spraw finansowych jednostek samorządu terytorialnego
}

Słowa kluczowe: regionalne izby obrachunkowe, kontrola finansowa, nadzór, gospodarka finansowa, zadania publiczne

Keywords: regional chambers of audit, financial control, supervision, financial policy, public duties

\section{Streszczenie}

Rozważania zawarte w artykule poświęcono problematyce nadzoru i kontroli sprawowanej przez regionalne izby obrachunkowe w stosunku do realizacji spraw finansowych jednostek samorządu terytorialnego. Rolą nadzoru jest wyznaczenie prawnych granic w zakresie możliwości ingerowania państwa na poziomie gmin, powiatów i województw w działalność tych jednostek. Fundamenty nadzoru i kontroli są efektem przyjęcia konstytucyjnej zasady demokratycznego państwa prawnego oraz zasady decentralizacji.

Celem opracowania jest dokonanie analizy normatywnej pozycji prawnej regionalnych izb obrachunkowych w aspekcie sprawowania nadzoru i kontroli nad działalnością finansową prowadzoną przez jednostki samorządu terytorialnego z uwzględnieniem zasady samodzielności. Regionalne izby obrachunkowe stanowią konstytucyjne, kolegialne organy państwa o szczególnym charakterze, wyposażone w kompetencje nadzorczo kontrolne, co czyni z nich gwaranta samodzielności jednostek samorządu terytorialnego w zakresie gromadzenia i wydatkowania środków publicznych z wykorzystaniem kryterium legalności.

1 ORCID ID: 0000-0002-2672-5072, magister, Zakład Prawa Finansowego, Instytut Nauk Prawnych, Kolegium Nauk Społecznych, Uniwersytet Rzeszowski. E-mail: lubina. joanna@gmail.com. 


\section{Abstract \\ The role of regional chambers of audit in the field of supervision and control financial matters of local government units}

The article aims at presenting role of regional chambers of audit in the field of control and supervision financial matters of local government's units perform their tasks according to the principles stipulated by the binding legal regulations. The role of supervision is to define legal boundaries in terms of the state's ability to intervene at the district, county or voivodeships level in the activities of these units. The foundations of supervision result from the adoption of the constitutional principle of a democratic state ruled by law and the principle of decentralization.

The aim of this study is to analyse the normative legal position of regional accounting chambers in terms of exercising control and supervision over financial activities carried out by local government units, while taking into account their autonomy. Regional chambers of audit are constitutional state bodies of a special nature, equipped with supervisory and control powers, which makes them the guarantor of the independence of local government units in the field of collecting and spending public funds using the legality criterion.

\section{Wprowadzenie}

Zagadnienie nadzoru i kontroli finansowej nad gminami, powiatami i województwami w powiązaniu z kryterium samodzielności jest istotne z perspektywy statusu samorządu terytorialnego jako ważnego elementu systemu prawnego Rzeczpospolitej Polskiej. Zadania publiczne przekazywane są do wykonania przez jednostki samorządu terytorialnego ${ }^{2}$, jednak to państwo dysponuje gwarancją nienaruszalności systemu prawnego poprzez instytucję nadzoru, która stosowana jest w przypadku, kiedy działalność administracji publicznej sprawowana jest na zasadzie decentralizacji władzy publicznej.

2 Dalej jako: j.s.t. 
Przekazanie pewnych kompetencji ze szczebla państwowego na poziom samorządowy stanowi urzeczywistnienie zasady samodzielności, która jest limitowana granicami określonymi poprzez nadzór. Działania nadzorcze wykonywane są zgodnie z obowiązującymi przepisami Konstytucji Rzeczypospolitej Polskiej ${ }^{3}$, Europejskiej Karty Samorządu Lokalnego ${ }^{4}$ oraz ustaw samorządowych ${ }^{5}$. Poza przepisami konstytucyjnymi oraz ustawą z 7 października 1992 r. o regionalnych izbach obrachunkowych ${ }^{6}$ pozycję prawną RIO regulują: rozporządzenie Prezesa Rady Ministrów z 16 lipca 2004 r. w sprawie siedzib i zasięgu terytorialnego RIO, szczególnej organizacji izb, liczby członków kolegium oraz trybu postępowania ${ }^{7}$.

Rolą regionalnych izb obrachunkowych ${ }^{8}$ jest prowadzenie nadzoru w zakresie działalności jednostek samorządu terytorialnego obejmującej sprawy gospodarowania środkami publicznymi oraz kontroli gospodarki finansowej. RIO należą do państwowych organów kontroli (nadzoru), które są zupełnie niezależne od innych organów nadzoru i kontroli oraz j.s.t ${ }^{9}$. Wśród innych głównych zadań RIO wymienić należy: sporządzanie opinii, raportów czy analiz, a także działalność o charakterze szkoleniowo - instruktażowym w obszarze objętym nadzorem i kontrolą.

3 Konstytucja Rzeczypospolitej Polskiej z 2 kwietnia 1997 r. (Dz.U. Nr 78, poz. 483 ze zm.), dalej jako: Konstytucja RP.

4 Europejska Karta Samorządu Lokalnego, sporządzona w Strasburgu 15 października 1985 r. (Dz.U. 1994, Nr 124, poz. 607 ze zm.), dalej jako: EKSL.

5 Regulacje prawne dotyczące nadzoru zawarte są w art. 171 Konstytucji RP, a ich rozwinięcie następuje w przepisach rozdziału X (art. 85-102) ustawy z 8 marca 1990 r. o samorządzie gminnym (t.j. Dz.U. 2020, poz. 713 ze zm.), rozdziału VIII (art. 76-90a) ustawy z 5 czerwca 1998 r. o samorządzie powiatowym (t.j. Dz.U. 2020, poz. 920 ze zm.) oraz rozdziału VII (art. 78-88a) ustawy z 5 czerwca 1998 r. o samorządzie województwa (t.j. Dz.U. 2020, poz. 1668 ze zm.). Dalej określane łącznie jako: ustawy samorządowe.

6 Ustawy z 7 października 1992 r. o regionalnych izbach obrachunkowych (t.j. Dz.U. 2019, poz. 2137 ze zm.), dalej jako: u.r.i.o.

7 Rozporządzenie Prezesa Rady Ministrów z 16 lipca 2004 r. w sprawie siedzib i zasięgu terytorialnego regionalnych izb obrachunkowych oraz szczegółowej organizacji izb, liczby członków kolegium i trybu postępowania (Dz.U. Nr 167, poz. 1747).

8 Dalej jako: RIO.

9 T. Dębowska-Romanowska, Regionalne izby obrachunkowe - nadzór zewnętrzny nad zarzadzaniem finansowym w samorzadzie i nad tworzeniem lokalnego prawa finansowego, [w:] Regionalne izby obrachunkowe. Charakterystyka ustrojowa i komentarz do ustawy, red. M. Stec, Warszawa 2010, s. 19. 
Funkcje sprawowania kontroli i nadzoru nie są tożsame, chociaż wykonuje je ten sam podmiot, a każdy z aktów nadzorczych jest poprzedzony kontrolą. Zarówno zakres uprawnień nadzorczych, jak i kontrolnych różni zakres podmiotowo-przedmiotowy, forma, tryb oraz uprawnienia władcze lub ich brak. Kontrola może mieć charakter samoistny, a może być elementem nadzoru. Kontrola samoistna nie umożliwia ingerencji podmiotu kontrolującego w działalność prowadzoną przez kontrolowanego ${ }^{10}$. Nadzór jest wykonywany przez Kolegium Izby, a kontrola może być przeprowadzana zarówno przez Kolegium, jak i składy orzekające.

Opracowanie przygotowane zostało w oparciu o przepisy obowiązującego prawa, orzecznictwo, oraz literaturę przedmiotu. Podsumowanie stanowią wnioski de lege lata oraz postulaty de lege ferenda. W celu zrealizowania tematyki artykułu wykorzystano metodę analizy formalno-dogmatycznej, opracowanie ma charakter teoretyczno-prawny, koncentrując się na wskazywaniu twierdzeń o określonych zjawiskach prawnych w oparciu o istniejący dorobek doktryny i orzecznictwa.

\section{Konstytucyjne ujęcie samodzielności samorządu terytorialnego}

Szeroko rozumiana samodzielność jest elementem kluczowym konstrukcji prawnej instytucji samorządu terytorialnego, w sferze: kształtowania ustroju wewnętrznego ${ }^{11}$, finansowej ${ }^{12}$, podatkowej ${ }^{13}$, majątkowej ${ }^{14}$ oraz publicznoprawnej ${ }^{15}$ poprzez samodzielne wykonywanie zadań publicznych. Konstytucja RP wyraźnie wskazuje podstawowe zadanie samorządu terytorialnego jakim jest zaspokajanie potrzeb zbiorowości samorządowej. Trybunał Konstytucyjny określił, że przyznane na gruncie Konstytucji RP uprawnienia dla j.s.t. nie mogą być wykonywane przez te jednostki w sposób dowolny, bowiem stanowią one środek do prawidłowego i efektywnego realizowania zadań publicz-

10 Por. uchwała TK z 5 października 1994 r. (W 1/94), „Orzecznictwo Trybunału Konstytucyjnego" 1994, nr 42, poz. 47.

11 Por. art. 169 ust. 4 Konstytucji RP.

12 Por. art. 167 Konstytucji RP.

13 Por. art. 168 Konstytucji RP.

14 Por. art. 165 ust. 1 Konstytucji RP.

15 Por. art. 163, 166 Konstytucji RP. 
nych ${ }^{16}$. Nadzór jest jednym $\mathrm{z}$ instrumentów, który pozwala na wyznaczenie granicy samodzielności j.s.t.

Samorząd terytorialny w Polsce funkcjonuje w oparciu o pewne zasady, do których zalicza się: zasada pomocniczości, decentralizacji, samodzielności. Zasada samodzielności j.s.t. oznacza w szczególności, określony zakres zadań własnych związanych z zaspokajaniem potrzeb mieszkańców oraz zadań zleconych określonych przez ustawy, posiadanie osobowości prawnej i przyznane j.s.t. prawo własności, a także ograniczoną ingerencję organów władzy wykonawczej w realizację zadań własnych, która dopuszczalna tylko w wypadkach określonych w ustawach w oparciu o kryterium legalności. Ingerencja w sferę samodzielności jednostek samorządu terytorialnego musi być zgodna z zasadą proporcjonalności, a prawa i interesy jednostek samorządu terytorialnego podlegają ochronie sądowej.

Fundamentów zasady samodzielności j.s.t. należy upatrywać w zasadzie subsydiarności, która oznacza pierwszeństwo wykonywania zadań na najniższym szczeblu, czyli na poziomie gminy. Zgodnie z zasadą decentralizacji jednostkom zapewnia się prawo samodzielnego oraz niezależnego wykonywania zadań, za które ponoszą odpowiedzialność, jednak ta niezależność pozostaje pod nadzorem właściwych organów państwowych. Samorząd terytorialny jest formą decentralizacji władzy publicznej, poprzez uczestnictwo w sprawowaniu władzy, wykonuje zadania publiczne we własnym imieniu i na własną odpowiedzialnośćc ${ }^{17}$.

W celu urzeczywistnienia skutecznego nadzoru należy określić katalog środków nadzoru wraz z zasadami zgodnie, z którymi organy nadzoru będą je stosować. Pośród instrumentów zaliczanych do „nowoczesnych środków nadzoru” należy wymienić przede wszystkim politykę legislacyjną, bowiem dzięki niej państwo może kształtować strukturę organizacyjną samorządu, jego zadania i kompetencje, zakres ingerencji nadzorczej, a także majątkowe i finansowe zabezpieczenia jego funkcjonowania oraz politykę fiskalną państwa. „Nowoczesne instrumenty” stwarzają dużo większe możliwości oddziaływania na samorząd niż tradycyjne środki nadzoru i to one, a nie tradycyjne środki nadzoru, przesądzają o rzeczywistym zakresie samodzielności samo-

\footnotetext{
16 Wyrok TK z 29 października 2009 r., K 32/08, OTK ZU 9/A/2009, poz. 139.

17 Por. art. 16 ust. 2 Konstytucji RP.
} 
rządu, jednak jest to możliwe jedynie przy uwzględnieniu założenia ich racjonalnego i przemyślanego ich stosowania, pozbawionego instrumentalnego charakteru ${ }^{18}$.

\section{III. Środki nadzoru}

Nadzór prowadzony w j.s.t. ma charakter przedmiotowy, czyli dotyczy działalności podmiotów j.s.t., a nie samych podmiotów. Nadzór obejmuje całokształt działalności jednostki, chociaż konkretne środki nadzoru mogą się odnosić jedynie do wskazanego zakresu.

Regionalne izby obrachunkowe ze względu na ich państwowy charakter są niezależne od jednostek samorządu terytorialnego. W doktrynie wskazywano, że może to zagrażać brakiem niezależności $\mathrm{RIO}^{19}$, poprzez możliwy nadmierny wpływ ze strony oddziaływania administracji państwowej, jednak Trybunał Konstytucyjny w jednym ze swoich orzeczeń wskazał, że wskazana regulacja nie powoduje braku niezależności RIO, ponieważ są one organami o statusie państwowym i nie są zależne od pionu centralnego administracji publicznej ${ }^{20}$.

RIO jako organy odpowiedzialne za prowadzenie kontroli i nadzoru zostały wyposażone w środki, które umożliwią im zrealizowanie tego celu. Prowadzone działania podejmowane są z określoną częstotliwością, co pozwala na dokonanie oceny podmiotu kontrolowanego i możliwość sprawdzenia na ile wprowadzone zostały zmiany. Artykuł 7 u.r.i.o. stanowi, że przeprowadzanie takiej kontroli powinno następować w maksymalnie czteroletnich okresach, jednak j.s.t. lub podmiot przekazujący środki może zawnioskować o przeprowadzenie kontroli, w celu sprawdzenia prawidłowego wydatkowania środków ${ }^{21}$.

18 J.Jagoda, Prawne przestanki samodzielności samorządu terytorialnego, [w:] Administracja publiczna pod rządami prawa. Księga pamiątkowa z okazji 70-lecia urodzin prof. zw. dra hab. Adama Błasia, red. J. Korczak, Wrocław 2016, s. 139-152.

19 A. Wiktorowska, Prawne determinanty samodzielności gminy. Zagadnienia administracyjnoprawne, Warszawa 2002, s. 192.

20 Wyrok TK z 28 kwietnia 1999 r., K 3/99.

21 K. Badurowicz, T. Drab, Status ustrojowy regionalnych izb obrachunkowych $i$ ich wptyw na procedurę budżetowa jednostek samorzadu terytorialnego, „Rocznik Samorządowy” 2016, nr 5, s. 9-21. 


\section{Uprawnienia regionalnych izb obrachunkowych w zakresie kontroli i nadzoru}

Pojęcie regionalna izba obrachunkowa pomimo jego powszechnego stosowania, należy doprecyzować, bowiem faktycznie uprawnienia nadzorcze sprawowane są przez Kolegium Izby ${ }^{22}$. Organ ten dysponuje wyłączną właściwością w zakresie m.in. orzekania o nieważności uchwał oraz zarządzeń podejmowanych przez organy j.s.t. Rozstrzygnięcia Kolegium Izby zapadają na posiedzeniach, poprzedzone są dyskusją, która umożliwia uzgodnienie końcowego stanowiska wobec stwierdzonego naruszenia prawa ${ }^{23}$. Każda z uchwał Kolegium zawiera uzasadnienie. Prezentowane rozważania dowodzą, że konstrukcja organu pozostaje w ścisłej zależności z charakterystyką wykonywanych przez niego zadań ${ }^{24}$.

Rezultatem przyznanych Kolegium Izby uprawnień nadzorczych nad gospodarką finansową j.s.t. jest konieczność zagwarantowania takiego sposobu dysponowania środkami publicznymi przez organy danej jednostki samorządu terytorialnego, aby w najbardziej skuteczny oraz efektywny sposób realizować zadania na rzecz wspólnoty lokalnej. RIO mają obowiązek wykorzystywać władczą ingerencję, w przypadku znacznego naruszenia obowiązujących przepisów, dysponując wówczas możliwością podjęcia decyzji o nieważności danej uchwały czy zarządzenia. Natomiast jeśli dane naruszenie jest mniejszej wagi, wówczas RIO poprzestaje na wskazaniu, że dany akt został wydany z naruszeniem przepisów prawa. Po przeprowadzonej w jednostce kontroli, opracowane zostają wystąpienie pokontrolne, które zawierają stwierdzone uchybienia oraz sposób ich wyeliminowania.

RIO mogą przeprowadzać kontrole w znaczeniu funkcjonalnym, polegające na ustaleniu stanu faktycznego, porównaniu go ze stanem postulowanym oraz jego ocenie. Mogą dokonywać kontroli określanych jako zarządcze, po-

22 Z. Dubiel, Regionalna izba obrachunkowa jako organ nadzoru nad dziatalnościa komunalna w zakresie spraw budżetowych, [w: Polska lat dziewięćdziesiątych. Przemiany państwa i prawa, red. M. Mozgawa, M. Nazar, J. Stelmasiak, T. Bojarski, Lublin 1997, s. 217.

23 A. Skibiński, Nadzór i kontrola nad samorządem terytorialnym $w$ Polsce wobec zasad wyrażonych w Europejskiej Karcie Samorządu Terytorialnego, „Casus” 2007, nr 45, s. 48.

24 E. Żelasko-Makowska, Organizacja organów administracji publicznej z punktu widzenia nadzoru nad działalnością samorządu terytorialnego, „Przegląd Naukowy Disputatio” 2015, t. XX, s. 67. 
legających na analizie sytemu zarządzania danej jednostki za pomocą określonych procedur, zasad, mechanizmów, schematów, instrukcji, które mają zagwarantować, że cele zarządzania zostaną osiągnięte ${ }^{25}$.

Uprawnienia kontrolne RIO obejmują kontrole gospodarki finansowej w zakresie realizacji zobowiązań podatkowych oraz zamówień publicznych w oparciu nie tylko o kryterium zgodności z prawem, a także zgodności ze stanem faktycznym dokumentów jednostki. Należy wskazać, że w zakresie zadań administracji rządowej wykonywanych na podstawie ustaw i porozumień kontrola gospodarki finansowej kontrola wykonywana jest przy wykorzystaniu również kryterium: celowości, rzetelności i gospodarności.

Regionalne izby obrachunkowe w zakresie swojej właściwości rzeczowej dysponują kompetencjami do dokonywania nadzoru nad uchwałami oraz zarządzeniami organów jednostek samorządu terytorialnego, jednak wyłącznie tych o charakterze finansowym. Określone w ustawie o regionalnych izbach obrachunkowych uprawnienia $\mathrm{RIO}^{26}$ powinny być rozpatrywane z uwzględnieniem określonych w sposób enumeratywny uchwał j.s.t., określonych w art. 171 ust. 2 Konstytucji RP. W tym przedmiocie należy odwołać się do orzeczenia Naczelnego Sądu Administracyjnego, który orzekł, że określenie „w sprawie” odnosi się do całokształtu kwestii powiązanych rzeczowo z zasadniczym, określonym hasłowo zagadnieniem, w tym przypadku $\mathrm{z}$ finansami. Zdaniem NSA wobec braku definicji legalnej pojęcia „sprawy finansowe”, w której zostałby oznaczony zakres spraw oddanych nadzorowi RIO wyłącznie do wymienionych w art. 11 ust. 1 u.r.i.o., to kompetencji nadzorczych RIO nie należy zawężać przez domniemanie kompetencji wojewody ${ }^{27}$.

Rozważania obejmujące zagadnienie określenia granic samodzielności j.s.t., podejmowania działań w sposób zgodny z prawem mając na uwadze doniosłość interesu społeczności lokalnej, jej potrzeby należy podejmować z jednoczesnym uwzględnieniem racjonalnego, efektywnego i skutecznego dysponowania środkami publicznymi ${ }^{28}$.

25 R.P. Krawczyk, Funkcja kontrolna regionalnych izb obrachunkowych-aktualne dylematy, „Finanse Komunalne” 2013, nr 1-2, s. 67.

26 Por. art. 11 ust. 1 u.r.i.o.

27 Wyrok NSA z 29 listopada 2007 r., sygn. II GSK 261/07 (LEX nr 368201).

28 J. Korczak, Nadzór i kontrola nad działalnością samorzadu terytorialnego, [w:] System Prawa Administracyjnego, red. R. Hauser, A. Wróbel, Z. Niewiadomski, t. 2, Warszawa 2012, s. 120-125. 
Przeprowadzona powyżej analiza pozycji ustrojowej RIO w zakresie przyznanych przez ustawodawcę funkcji nadzorczych i kontrolnych oraz działalności opiniodawczej, instruktażowej i szkoleniowej pozwala na wyciągnięcie poniższych wniosków. Regionalne izby obrachunkowe są organami konstytucyjnymi o szczególnym charakterze, dysponującymi nadzorczo - kontrolnymi uprawnieniami wobec j.s.t., które zostały określone w zamkniętym katalogu organów nadzoru, a podejmowane przez nie działania w żaden sposób nie zmniejszają samodzielności j.s.t., stanowiąc wyznacznik tej samodzielności w kontekście gospodarki finansowej.

\section{Uwagi końcowe}

Jako wniosek de lege lata należy stwierdzić, ze organy wyspecjalizowane, do których należy zaliczyć regionalne izby obrachunkowe stanowią główne narzędzie do prowadzenia stałego nadzoru i kontroli działalności jednostek samorządu terytorialnego, przyczyniając się do poprawy sprawności administracji na poziomie lokalnym i regionalnym. Zadanie publiczne realizowane przez administrację publiczną powinny być zgodne z obowiązującymi przepisami prawa, ale także uwzględniać oczekiwania lokalnych społeczności. Oparcie stosunków administracyjnych na zasadach władztwa i podporządkowania wcale nie musi mieć charakteru bezwzględnego. W przypadku stwierdzenia przez jednostkę, że organ administracji publicznej nieprawidłowo realizuje swoje kompetencje, dysponuje ona możliwością dochodzenia swoich praw przed niezależnym organem sądowym ${ }^{29}$. Zagadnienia zewnętrznego i wewnętrznego oddziaływania na wykonywanie zadań publicznych są bezpośrednio związane z instytucją nadzoru i kontroli.

Zmiany pozycji regionalnych izb obrachunkowych w kontekście ich rosnącej roli jako podmiotu uprawnionego do sprawowania wyspecjalizowanej kontroli w obszarze działalności finansowej oraz nadzoru nad działalnością samorządu terytorialnego i innych jednostek sektora finansów publicznych należy ocenić pozytywnie. Przekazywanie nowych zadań regionalnym izbom obrachunkowym sprawia, że należy stale podnosić także wymagania w za-

29 K. Małysa-Ptak, Kontrola działalności publicznej sprawowana przez sądy powszechne, Warszawa 2019, s. 72-77. 
kresie kryteriów dla kandydatów, którzy będą pełnili funkcje w organie kolegialnym, czyli Kolegium Izby. W kontekście wskazanych postulatów de lege ferenda wymaga podkreślenia, że zachodzące zmiany w zakresie kształtowania statusu prawnego regionalnych izb obrachunkowych, dotyczą w szczególności znaczenia Kolegium Izby. Ten wyspecjalizowany organ sprawuje funkcje nadzorcze, kontrolne, wszystkie z uwzględnieniem granic podmiotowych i przedmiotowych swojej właściwości przy zwiększonej specjalizacji wymagającej angażowania różnych instrumentów nadzorczych, kontrolnych lub niewładczych na każdym etapie. Proces zmian w zakresie rozwiązań regulujących pozycje i znaczenie regionalnych izby obrachunkowych nie jest nadal zakończony, co potwierdzają dyskusje ciągle aktualnej potrzebie zmian w dotychczasowych rozwiązania prawnych i wykorzystywanych środkach nadzoru.

\section{Literatura}

Badurowicz K., Drab T., Status ustrojowy regionalnych izb obrachunkowych i ich wplyw na procedurę budżetowa jednostek samorządu terytorialnego, „Rocznik Samorządowy" 2016, nr 5.

Dębowska-Romanowska T., Regionalne izby obrachunkowe - nadzór zewnętrzny nad zarządzaniem finansowym $w$ samorządzie i nad tworzeniem lokalnego prawa finansowego, [w:] Regionalne izby obrachunkowe. Charakterystyka ustrojowa i komentarz do ustawy, red. M. Stec, Warszawa 2010.

Dubiel Z., Regionalna izba obrachunkowa jako organ nadzoru nad działalnościa komunalna w zakresie spraw budżetowych, [w:] Polska lat dziewięćdziesiątych. Przemiany państwa i prawa, red. M. Mozgawa, M. Nazar, J. Stelmasiak, T. Bojarski, Lublin 1997.

Jagoda J., Prawne przesłanki samodzielności samorząu terytorialnego, [w:] Administracja publiczna pod rządami prawa. Księga pamiatkowa $z$ okazji 70-lecia urodzin prof. $z w$. dr hab. Adama Błasia, red. J. Korczak, Wrocław 2016.

Korczak J., Nadzór i kontrola nad działalnością samorzadu terytorialnego, [w:] System Prawa Administracyjnego, red. R. Hauser, A. Wróbel, Z. Niewiadomski, t. 2, Warszawa 2012.

Krawczyk M., Podstawy władztwa administracyjnego, Warszawa 2016.

Krawczyk R.P., Funkcja kontrolna regionalnych izb obrachunkowych -aktualne dylematy, „Finanse Komunalne” 2013, nr 1-2.

Małysa-Ptak K., Kontrola działalności publicznej sprawowana przez sądy powszechne, Warszawa 2019. 
Skibiński A., Nadzór i kontrola nad samorządem terytorialnym $w$ Polsce wobec zasad wyrażonych w Europejskiej Karcie Samorzadu Terytorialnego, „Casus” 2007, nr 45.

Wacinkiewicz D., Kontrola i nadzór w prawie komunalnym, Warszawa 2007.

Wiktorowska A., Prawne determinanty samodzielności gminy. Zagadnienia administracyjnoprawne, Warszawa 2002.

Witalec W., Granice prawne wydatków samorzadu terytorialnego w świetle orzecznictwa regionalnych izb obrachunkowych, „Finanse Komunalne” 2010, nr 6.

Żelasko-Makowska E., Organizacja organów administracji publicznej z punktu widzenia nadzoru nad działalnością samorządu terytorialnego, „Przegląd Naukowy Disputatio" 2015, t. XX. 